\title{
Historein
}

Vol $11(2011)$

Politics and History

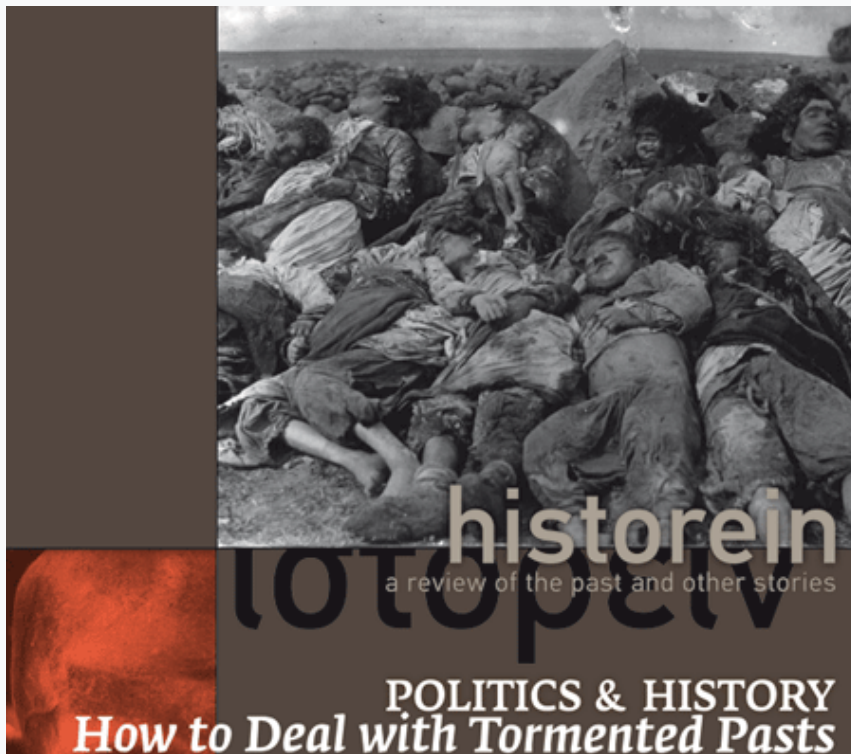

\section{Conceptualising Historical Crimes}

Antoon De Baets

doi: $10.12681 /$ historein. 140

Copyright $\odot$ 2012, Antoon De Baets

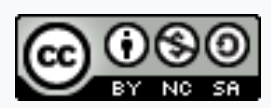

This work is licensed under a Creative Commons Attribution-NonCommercialShareAlike 4.0.

\section{Pierre Nora}

Jörn Rüsen

Wolfgang Benz

Luigi Cajani

Antoon De Baets

To cite this article:

De Baets, A. (2012). Conceptualising Historical Crimes. Historein, 11, 59-68. https://doi.org/10.12681/historein.140 
Should crimes committed in the course of history that are comparable to genocide, crimes against humanity or war crimes be referred to as such, whatever the label used at the time?' This is the question I want to examine below. Let us compare the problems of labelling historical crimes with historical and recent concepts, respectively. ${ }^{2}$

\section{Historical concepts for historical crimes}

"Historical concepts" are terms used to describe practices by the contemporaries of these practices. Scholars can defend the use of historical concepts with the argument that many practices deemed inadmissible today (such as slavery, human sacrifice, heritage destruction, racism, censorship, etc.) were accepted as rather normal and sometimes even as morally and legally right in some periods of the past. Arguably, then, it would be unfaithful to the sources, misleading and even anachronistic to use the present, accusatory labels to describe them. This would mean, for example, that one should not call the crimes committed during the Crusades crimes against humanity (even if a present observer would have good reason to qualify some of these crimes as such), for such a concept was nonexistent at the time. A radical variant of the latter is the view that not only recent labels should be avoided but even any moral judgments of past crimes.

This argument, however, can be countered with several objections. First, diverging judgments. It is well known that parties

\section{Conceptualising \\ Historical Crimes}

\section{Antoon De Baets}

University of Groningen 
involved in violent conflicts label these conflicts differently. And different terms imply different moral judgments, as Isaiah Berlin showed long ago:

In describing what occurred I can say that so many million men were brutally done to death; or alternatively, that they perished; laid down their lives; were massacred; or simply, that the population... was reduced, or that its average age was lowered; or that many men lost their lives. None of these descriptions of what took place is wholly neutral: all carry moral implications ... The use of neutral language ("Himmler caused many persons to be asphyxiated") conveys its own ethical tone. ${ }^{3}$

In 2000, for example, the Council of Europe reported that the war of 1992-1995 in Bosnia and Herzegovina was referred to as "aggression" in Bosniac history textbooks, a "civil war" in Serbian history textbooks and a "war of liberation" in Croatian history textbooks. ${ }^{4}$

Second, euphemistic judgments. The opinions of contemporaries about such crimes usually diverge. On the one hand, at least some of the groups of contemporaries perceived as normal historical acts that would today be considered criminal - and it would be interesting to study this socalled normality and its context in contrast to the present-day situation. On the other hand, some groups of contemporaries did condemn the acts deemed criminal today and, in the process, invoked existing principles of humanity in defence of the victims, even if these principles were not as formalised as today. Almost certainly, a general, let alone unanimous, perception of acts deemed criminal today as "normal" was rare. Nevertheless, serious crimes from the past often received names which were perceived as euphemistic, even for many of those directly involved: "uprising" for "civil war" (the nationalists in their conflict with the republicans in Spain from 1936 to 1939), "final solution" for "extermination" (Nazi Germany towards the Jews), "police actions leading to excesses" for "war leading to war crimes" (the Netherlands fighting Indonesia's independence from 1945 to 1949), and "order-keeping operation" for "colonial war" (France in Algeria during the independence struggle from 1954 to 1962). If the euphemisms were taken at face value, they could have serious consequences: soft expressions (police actions, order-keeping operations) do not have an imprescriptible character, whereas strong ones (war crimes) do.

Third, politically inspired judgments. A variant of the argument in favour of the use of historical concepts is politically inspired. Political leaders and pressure groups may take the view that the past is unique and that therefore crimes from the past are incomparable to those in the present and that both deserve their own labels. This view is often inspired by a strong desire to avoid unfavourable historical parallels. ${ }^{6}$ Clearly, postulating complete incomparability over time is often self-serving. It is also radical: whoever takes such a position makes historical scholarship impossible.

Such are the objections against the use of historical concepts to label historical crimes. Let us now examine the other side. 


\section{Recent concepts for historical crimes}

The use of recent concepts can be defended with two arguments. First, compared to the relative arbitrariness with which many of the historical terms are used, legal concepts such as genocide, crimes against humanity and war crimes are defined very precisely. Second, many concepts are created long after the realities they describe. As Hans Reichenbach and Karl Popper, among others, have shown, the context of discovery is different from the context of justification. Popper spoke about theories, but it is no different for concepts: concepts that were created in one (legal) context can often be used in another (historical) context in a scientifically justifiable way. Malicious intentions, criminal premeditation, widespread or systematic attacks on civilian populations, mass killings, inhuman policies and other essential ingredients of gross crimes are phenomena pertaining to all times. Therefore, there is no intrinsic reason why present labels could not serve for past crimes.

The 1948 Genocide Convention itself acknowledges that genocide was a crime that occurred throughout history, because its preamble reads: "Recognising that at all periods of history genocide has inflicted great losses on humanity and [b]eing convinced that, in order to liberate mankind from such an odious scourge, international co-operation is required."7 Indeed, the Holocaust of 19391945 has officially been called a genocide since the adoption of the Genocide Convention. ${ }^{8}$ Nobody can protest in earnest against this case of retroactive labelling because the Genocide Convention was drafted precisely with the Nazi atrocities in the minds of the drafters. From 1975, the Armenian massacres of 1915 were also increasingly called a genocide and not only because they seemed to fit the 1948 definition so well but also because the inventor of the genocide concept, the PolishJewish lawyer Raphael Lemkin, developed the idea behind it when in the 1920s he learnt about the Armenian massacres. How sensitive this issue is may be inferred from the following incident. A United Nations photo exhibition on the 1994 Rwandan genocide, which was scheduled to open in April 2007, was dismantled because of Turkish objections to a reference which read: "During World War I, a million Armenians were murdered in Turkey." The reference was intended to explain the connection between the Armenian massacres and Lemkin's concept of "genocide". Although the words "in Turkey" were removed after diplomatic consultations, the exhibition was postponed.

Other massacres were also labelled as genocide in a 1985 United Nations document, the socalled Whitaker Report:

The Nazi aberration has unfortunately not been the only case of genocide in the twentieth century. Among other examples which can be cited as qualifying are the German massacre of Hereros in 1904, the Ottoman massacre of Armenians in 1915-1916, the Ukrainian pogrom of Jews in 1919, the Tutsi massacre of Hutu in Burundi in 1965 and 1972, the Paraguayan massacre of Ache Indians prior to 1974, the Khmer Rouge massacre in Kampuchea between 1975 and 1978, and the contemporary Iranian killings of Baha'is. ${ }^{10}$

Several objections have been launched against the use of recent concepts. First, the arbitrary or limited character of unofficial recent concepts and definitions. If historical concepts can be arbitrary or limited, so can recent ones. Sometimes, scholars use concepts different from courtsanctioned labels. In 2001, for example, the International Criminal Tribunal for the Former Yu- 
goslavia ruled that the mass murder of July 1995 in Srebrenica was a genocide. Despite the fact that the historians from the Netherlands Institute for War Documentation repeatedly used this judgment in their 2002 report about the Srebrenica events (but without mentioning even once that the tribunal had called them a genocide), they labelled it a "mass murder" for reasons of neutrality. This was unconvincing because a mass murder, however terrible, is different from a genocide. After 2002, the tribunal kept calling the Srebrenica murders a genocide in many new verdicts, which were confirmed by a judgment of the International Court of Justice in 2007."

Obviously, such conceptual problems also penetrate definitions. Twenty years ago, Frank Chalk and Kurt Jonassohn coordinated a study of 20 genocides in history. As one of the first works of its kind, it became a strong study but it had one major flaw: the authors did not adopt the United Nations definition of genocide to identify the historical cases of genocide; instead, they developed a broader definition of their own. ${ }^{12}$ Even if it is true that the official definitions of genocide and similar concepts are controversial and partially the product of compromise, often obtained after long years of diplomacy, it is difficult to defend the use of recent concepts for historical crimes if scholars apply their own working definitions. Historians can certainly deviate from official concepts and definitions, but they should convincingly justify why their alternative is better. Even if their justification succeeds, they pay the price of lowering the comparability of their work.

Second, difficult categorisation. Official definitions of genocide, crimes against humanity, and war crimes are precise, but also detailed. This complicates the task of proving beyond reasonable doubt the facts for each of the elements of the definition. If a crime transforms from a mass murder into, for example, a genocide, the burden of proof becomes more severe. This is the reason why almost without exception all genocides, also historical ones, provoke acrimonious debates about crucial aspects of the crime such as victim group types, chains of command and perpetrator intent and motives as inferred from the planning and scale of the crime. An example is the Holodomor ("death from hunger"), the famine of 1932-1933 which was called a genocide by the Ukrainian government of Viktor Yushchenko in 2008. That same year, however, the European Parliament labelled it a crime against humanity, not a genocide. In 2010, the succeeding president, Viktor Yanukovych, declared in the Parliamentary Assembly of the Council of Europe that the Holodomor had affected many nationalities and ethnic groups, and that therefore it was not fair to label it a genocide. The president was promptly sued for defamation. ${ }^{13}$

Similar problems arise when we label practices as "crimes against humanity" and "war crimes" (both concepts having entered into international criminal law in 1945). In a rare study from 1997 about the impunity of perpetrators of violations of economic, social and cultural rights, the United Nations Commission on Human Rights explored four, of what it called, "historical precedents" of such violations: apartheid, slavery, the looting of cultural heritage and colonisation. The rapporteur of the study even called these precedents "crimes against humanity".14 It is interesting to look at when these four precedents were labelled as crime categories for the first time. The United Nations called apartheid a subcategory of "crimes against humanity" in 1966. As to the second precedent, the International Criminal Court Statute determined that enslavement (a summary name for slavery and slave trade) was a subcategory of "crimes against humanity" in $1998 .{ }^{15} \mathrm{As}$ to the third precedent, one extreme variant of the looting of cultural heritage, the destruction of historic monuments, if 
carried out without overriding military necessity, was called a war crime in the two 1977 Protocols Additional to the Geneva Conventions. In 1998 the International Criminal Court saw this destruction also as a form of persecution, which is a subcategory of "crimes against humanity". ${ }^{16}$ The first judgment in this regard (by the International Criminal Tribunal for the Former Yugoslavia) was pronounced in $2006 .{ }^{17}$ As to the last precedent, many forms of colonisation were accompanied by acts that would doubtlessly be called crimes against humanity today. King Leopold II's Congo Free State (1885-1908) is an example. In some cases, colonisation even led to war crimes (during ruthless campaigns for expansion) or genocide (as with the massacre of Hereros in German South-West Africa, present-day Namibia, in 1904). ${ }^{18}$ Thus, it is indeed defensible to categorise some types of these four "historical precedents" as crimes against humanity. In addition, some types may fall under two or three labels: "destroying historic monuments" can be a crime against humanity or a war crime, and "colonial punitive expeditions" (if they meet strict conditions) a war crime or genocide.

Third, shifting categorisation. Labels can shift. In 1992, the United Nations General Assembly called "ethnic cleansing" a form of genocide, but in 2007, the International Court of Justice declared that ethnic cleansing was not a crime, but a policy that could include genocide. ${ }^{19}$ Such examples are rare at the international level but rather common when they become the object of national party politics (as the Ukrainian example has shown).

Fourth, complex case law. Like categorising, judging concrete cases can be quite complex. In 2008, for example, the Grand Chamber of the European Court of Human Rights ruled (11 to 6) that the 1994 conviction of a retired military officer for crimes against humanity for quelling a riot during the Hungarian Revolution of October 1956 was unjustified. On the one hand, it was not shown that the act of this officer formed part of a widespread attack on the civilian population; on the other it was proven that at least one of the victims was a combatant. Therefore, the officer could not have foreseen that his orders and shots constituted a crime against humanity..$^{20}$ Also in 2008, a chamber of the European Court of Human Rights controversially ruled ( 4 to 3 ) that a punitive military operation by Soviet partisans in Mazie Bati, Latvia, in May 1944, could not be called a war crime. The case was referred to the court's Grand Chamber, which in May 2010 reversed the ruling by judging (14 to 3 ) that it had indeed been a war crime and that the rule "no punishment without law" had not been violated. ${ }^{21}$

Fifth, challenges to categorisation. In October 2008, Judge Baltasar Garzón attempted to initiate a case against Franco and his generals for crimes against humanity during the civil war and the early period of the ensuing dictatorship (1936-1952). He maintained that he was permitted to investigate these crimes against humanity because they had no statute of limitations. A month later, however, judges from the Spanish National Court forced Garzón to drop the case with the arguments that the alleged perpetrators were dead and that the crimes were covered by an amnesty passed in 1977. Garzón's decision not to apply this amnesty law, however, was supported by international treaty and customary law, which impose on states a duty to investigate the worst international crimes, including crimes against humanity. In 2008, for example, the United Nations Human Rights Committee called on Spain to repeal the amnesty law and to ensure that domestic courts did not apply limitation periods to crimes against humanity. In May 2010, the General Council of the Judiciary suspended Garzón from duty for the duration of his trial for abuse of power before the Supreme Court.22 
Sixth, politically inspired categorisation. As the use of the term genocide expresses the strongest possible condemnation of a crime, victim groups and their spokespersons are eager to use "genocide" as a trump card. Recently, a judge called the massacre of about 300 students at in the Tlatelolco district of Mexico City in October 1968 a genocide, but it is difficult to see how students fall under one of the four groups (national, ethnic, racial, religious) mentioned in the 1948 genocide definition. This judgment was overruled. ${ }^{23}$ To give another example: some define slavery inaccurately as a genocide or a "Black Holocaust", but the slave traders' intent was not to destroy the slaves but to exploit them as cheap labour. ${ }^{24}$ In a French legal case from 2005, the terms crimes against humanity and genocide were confused. The Collective of Antilleans, Guyanese and Réunionnais (Collectifdom) sued historian Olivier Pétré-Grenouilleau in Paris because he allegedly denied in an interview that the slave trade was a crime against humanity - whereas the 2001 Taubira law had given it this status. In the interview, however, Pétré-Grenouilleau had said that the slave trade was a crime against humanity but not a genocide. Observers thought that the real motive behind the accusation was Pétré-Grenouilleau's 2004 book Les Traites négrières: Essai d'histoire globale [The black slave trade: an essay in global history], which viewed the slave trade as a phenomenon lasting thirteen centuries on five continents, of which the European slave trade (1500-1900) was but one part. The charges were dropped in $2006 .{ }^{25}$

Seventh, penalisation for deviant categorisation. Not only in France (as in the case of the Taubira law) but also elsewhere - in countries as diverse as Russia and Rwanda - so-called "memory laws" are regularly adopted, laws that seek to define the collective memory on a controversial historical subject by prescribing how people ought to think about certain historical episodes and by criminalising the denial of imprescriptible crimes (such as the Armenian genocide, the Holocaust or the Rwandan genocide). Article 19, a nongovernmental organisation, aptly formulated why such laws ought to be rejected:

Memory laws too often end up elevating history to dogma... Such laws are both unnecessary - since generic hate speech laws already prohibit incitement to hatred - and open to abuse to stifle legitimate historical debate and research ... [B]ecause they are open to abuse, the risk of disproportionate harm to freedom of expression is significant ... It is very clear that international law protects merely offensive, as opposed to harmful, speech. ${ }^{26}$

States should prohibit the public condoning, denying or grossly trivialising of genocide, crimes against humanity and war crimes only when they are forms of hate speech (that is, according to the United Nations, any advocacy of national, racial or religious hatred that at the same time constitutes incitement to discrimination, hostility or violence). ${ }^{27}$ In practice, most of the public condoning, denying or grossly trivialising of these grave crimes does not meet the incitement standard. ${ }^{28}$

The debate about the use of recent concepts for historical crimes implies that historians should develop a position vis-à-vis others who label crimes: politicians, legislators and judges. Politicians should not prescribe how history is written and therefore historians can neglect political views in principle (though often not in practice). ${ }^{29}$ When laws are adopted, historians should obey them, but this does not exclude the possibility to protest against national "memory laws" that again want to command a "correct" reading of history. In hate-speech matters, historians should 
defend the narrow universal standard laid down in article 20.2 of the International Covenant on Civil and Political Rights. When judges are independent (and most international and many national judges are), their decisions have to be reckoned with. Deviation from the concepts used by these judges can only be justified through a better alternative.

\section{Conclusion}

Given all of the above arguments and positions, balancing historical against recent concepts is not easy, although some tentative guidelines can be given. To begin with, historians should always mention the historical concepts, that is, how certain crimes were named by different parties at the time of their occurrence, and discuss the meaning of such names. Readers can then judge for themselves if and why the author prefers to deviate from the historical vocabulary. Furthermore, it has been clearly shown that the use of recent concepts is not necessarily anachronistic and often plainly better. In addition, if one rejects historical concepts and uses recent concepts instead, it is permissible, though often confusing, to develop one's own definitions for concepts that have already been defined under international law (as many scholars have done for the genocide concept). To be sure, scholars and others retain the right not to adopt labels defined under international law for historical practices. They should, however, explain why their alternative label or definition is superior. In cases where the victims or perpetrators of these crimes are still alive, it is not recommended that historians define the nature of a given crime differently from international courts, with their elevated standards of evidence and huge research departments. In cases where all the victims and perpetrators of these crimes are dead, the use of either historical or recent concepts has to be pain-stakingly justified. ${ }^{30}$

\section{NOTES}

1 I found the first mentions of the term "crimes against humanity" in 1915 (if an earlier mention of 1854 in another context is excluded), of "war crimes" in 1934 and of "genocide" in 1943-1944. For "crimes against humanity" and "war crimes", see articles 6b-6c of the charter of the International Military Tribunal (IMT) at Nuremberg (1945); for "genocide", see article 2 of the Convention on the Prevention and Punishment of the Crime of Genocide (1948). For presently internationally accepted definitions, see the statute of the International Criminal Court (ICC): article 6 for genocide (definition identical to article 2 of the Genocide Convention), article 7 for crimes against humanity (this definition is a complete redrafting of the IMT text), and article 8 for war crimes (a definition based on the 1949 Geneva Conventions and the $1977 \mathrm{Ad}$ ditional Protocols). For the 1854 use of crime against humanity, see Jonathan Yovel, "How Can a Crime Be Against Humanity? Philosophical Doubts Concerning a Useful Concept", UCLA Journal of International Law and Foreign Affairs 11 (2007), 39-58, here 56. The so-called Whitaker Report attributes the coinage of the term "crimes against humanity" to Hersch Lauterpacht; see United Nations (UN) Subcommission on Prevention of Discrimination and Protection of Minorities, Revised and Updated Report on the Question of the Prevention and Punishment of the Crime of Genocide [Whitaker Report] (E/CN.4/ Sub.2/1985/6; 2 July 1985), paragraph 74.

2 Complete versions of most human rights instruments and legal cases mentioned in this essay are avail- 
able at www.concernedhistorians.org. I thank Jeanne Pia Mifsud Bonnici, Rosalind Franklin fellow at the Faculty of Law of the University of Groningen, for her thoughtful comments. A preliminary, much shorter, Dutch version of this paper appeared as part of "Onverjaarbare historische misdrijven", Internationale Spectator 64/5 (2010), 293-297, here 294-296. The text was also part of a paper delivered as a contribution to the panel "History and Human Rights" at the 21st International Congress of Historical Sciences (Amsterdam, 23 Aug 2010). In addition, it was a contribution to the panel "History and Universal Justice" at the Fourth International Congress of History under Debate (Santiago de Compostela, 19 Dec 2010).

3 Isaiah Berlin, "Historical Inevitability”, in Idem, Four Essays on Liberty, Oxford: Oxford UP, 1969 [1954], xxix, also 95, 115.

4 Council of Europe (Parliamentary Assembly), Education in Bosnia and Herzegovina: Report (Doc. 8663) (Online), 14 Mar 2000, paragraph II, 4g.

5 See also Toby Mendel, Study on International Standards Relating to Incitement to Genocide or Racial Hatred: For the UN Special Advisor on the Prevention of Genocide (Halifax, Canada: April 2006, available at www.concernedhistorians.org/to/239.pdf), 8: “'Direct' incitement [to commit genocide] is more problematical to define, in part because it goes to the heart of what constitutes incitement ... and in part because of the ingenuity of human beings, including in the commission of heinous crimes, whereby euphemisms or implicit forms of speech may be employed to largely the same effect as clear calls to commit genocide."

6 I thank Peter Gran for drawing my attention to this argument.

7 See also the Whitaker Report, paragraphs 14-24.

8 The IMT Charter did not yet contain the genocide category. The UN General Assembly first affirmed that genocide was a crime under international law in Resolution 96 (I) (“The Crime of Genocide"), 11 Dec 1946.

9 Warren Hoge, “UN Genocide Exhibit Dismantled after Turkey Complains”, New York Times (Online), 10 Apr 2007.

10 Whitaker Report, paragraph 24.

11 See my discussion in "Na de genocide: Waarheidsstrategieën van rechters en historici" [After the genocide: truth strategies of judges and historians], Tijdschrift voor geschiedenis 116/2 (2003), 224-229.

12 Frank Chalk and Kurt Jonassohn, The History and Sociology of Genocide: Analyses and Case Studies, New Haven and London: Yale UP, 1990. For evidence that genocide is not a new phenomenon, see Peter Singer, One World: The Ethics of Globalization, New Haven, CT: Yale UP, 2002, 106-110.

13 European Parliament, "Resolution on the Commemoration of the Holodomor, the Ukraine Artificial Famine (1932-1933)”, 23 Oct 2008; Kyiv Post (Online), 30 Mar 2009; “Ukrainian Sues Yanukovych Over Famine Statement”, Radio Free Europe/Radio Liberty (Online) 15 Jun 2010.

14 UN Commission on Human Rights, Final Report on the Question of the Impunity of Perpetrators of Human Rights Violations (Economic, Social and Cultural Rights) (1997), paragraphs 28-52, especially paragraph 32. The plea of its author, El Hadji Guissé, to expand the 1985 UN definition of a victim (paragraph 137: "The status of victim and the rights attaching thereto are transmissible to the successors. This concept of successor should be understood in a wide sense") was not taken up. See also UN Subcommission on the Promotion and Protection of Human Rights, Recognition of Responsibility and Reparation for Massive and Flagrant Violations of Human Rights Which Constitute Crimes against Humanity and 
Which Took Place During the Period of Slavery, of Colonialism and Wars of Conquest: Resolution 2002/5 (2002). This resolution was preceded by Decision 2000/114 and Resolution 2001/1.

15 Apartheid: UN General Assembly, Resolution 2202 (XXI) (1966) and UN, International Convention on the Suppression and Punishment of the Crime of Apartheid (1973); enslavement: ICC, Statute (1998), articles 7.1(c), 7.2(c); slavery/slave trade: World Conference against Racism, Racial Discrimination, Xenophobia and Related Intolerance, Declaration (2001), article 13.

16 Geneva Conventions Protocol I (1977), articles 53(a), 85.4(d), and II (1977), article 16; ICC, Statute, articles 8.2(b)ix, 8.2(e)iv.

17 International Criminal Tribunal for the Former Yugoslavia, Prosecutor v. Momčilo Krajišnik; Case no. IT-00-39-T: Judgement (wWw.un.org/icty; 2006), paragraphs 780-783, 836-840.

18 More examples in Marc Ferro (ed.), Le Livre noir du colonialisme: XVle-XXIe siècle, de l' extermination à la repentance, Paris: Robert Laffont, 2003.

19 UN General Assembly, Resolution 121 (The Situation in Bosnia and Herzegovina) (1992); International Court of Justice, Case Concerning the Application of the Convention on the Prevention and Punishment of the Crime of Genocide (Bosnia and Herzegovina v. Serbia and Montenegro): Judgment (2007), paragraph 190.

20 European Court of Human Rights (ECHR), Case of Korbély v. Hungary (Application no. 9174/02): Judgment, 19 Sept 2008. The case was discussed under article 7 of the European Convention on Human Rights (the legality principle: no one can be held guilty for acts that were not criminal at the time they were committed). The canonical formulation of this nullum crimen sine lege principle is article 11 of the Universal Declaration of Human Rights (1948): "No one shall be held guilty of any penal offence on account of any act or omission which did not constitute a penal offence, under national or international law, at the time when it was committed."

21 ECHR, Case of Kononov v. Latvia (Application no. 36376/04): Judgment, 24 Jul 2008; ECHR (Grand Chamber), Case of Kononov v. Latvia (Application no. 36376/04): Judgment, 17 May 2010.

22 Amnesty International (Al), Report 2010, London: Al, 2010, 298, 300; Report 2009, London: Al, 2009 , 301, 303; Guardian (Online), 17 Oct 2008; New York Times (Online), 17 Oct 2008, 19 Nov 2008; The Times (Online), 19 Nov 2008. For another case, see David Oldroyd, “Anachronism and the 'History Wars' in Australia", Scientia Poetica 10 (2006), 337-365 (discussing whether the resistance of indigenous Tasmanians against the white settlers between 1824 and the mid-1830s can be called guerrilla warfare and whether their eventual disappearance was a case of ethnic cleansing and genocide). For a case in which it was attempted to solve ancient wrongs by law - the Waitangi Tribunal in New Zealand (established in 1975) - see Rosalyn Higgins, "Time and the Law: International Perspectives on an Old Problem”, International and Comparative Law Quarterly 46 (July 1997), 510-511.

23 Al, Report 2006, London: Al, 2006, 182; Al, Report 2007, London: Al, 2007, 25, 184; Al, Report 2008, London: Al, 2008, 16, 205; Al, Report 2009, London: Al, 2009, 226; Human Rights Watch (HRW), World Report 2006, Washington: HRW, 2006, 203; HRW, World Report 2007, Washington: HRW, 2007, 218; HRW, World Report 2008, Washington: HRW, 2008, 220-221.

24 Gert Oostindie, "Slavernij, canon en trauma: debatten en dilemma's" [Slavery, canon and trauma: debates and dilemmas], Tijdschrift voor geschiedenis 121/1 (2008), 8-9, 18.

25 In December 2005, 19 historians, including Pierre Nora (Pétré-Grenouilleau's publisher at Gallimard), 
signed a petition in support of Pétré-Grenouilleau and in protest against the increasing judicialisation of history in France, and founded an association called Liberté pour l'histoire with the aim of abolishing all French laws that regarded specific historical questions and restricted the freedom of historians. The petition was eventually signed by more than 550 historians. For the affair, see, among others, Libération (Online), 30 Nov 2005, 8 Jun 2006, 10 Aug 2006, and René Rémond, Quand l'État se mêle de l'Histoire, Paris: Stock, 2006, 8, 38-40, 94-95. For the context of the problem of memory laws (lois mémorielles), see Winfried Schulze, “Erinnerung per Gesetz oder 'Freiheit für die Geschichte?', Geschichte in Wissenschaft und Unterricht 59/7-8 (2008), 364-381 (373 for the Pétré-Grenouilleau case).

26 Article 19, “France: No More 'Memory Laws'” (press release), 26 Nov 2008. General Comment No. 34 (Article 19: Freedoms of Opinion and Expression) (Geneva, 21 July 2011) provided by the Human Rights Committee, is very clear in its paragraph 49: "Laws that penalise the expression of opinions about historical facts (so called "memory laws") are incompatible with the obligations that the Covenant [on Civil and Political Rights] imposes on States parties in relation to the respect for freedom of opinion and expression. The Covenant does not permit general prohibition of expressions of an erroneous opinion or an incorrect interpretation of past events." For a consistent approach, see Article 19, The Camden Principles on Freedom of Expression and Equality, London: Article 19, 2009, principles 12.1-12.3: "(12.1) All States should adopt legislation prohibiting any advocacy of national, racial or religious hatred that constitutes incitement to discrimination, hostility or violence (hate speech) ... (12.2) States should prohibit the condoning or denying of crimes of genocide, crimes against humanity and war crimes, but only where such statements constitute hate speech as defined by Principle 12.1. (12.3) States should not prohibit criticism directed at, or debate about, particular ideas, beliefs or ideologies, or religions or religious institutions, unless such expression constitutes hate speech as defined by Principle 12.1."

27 Hate speech as defined in article 20.2 of the International Covenant on Civil and Political Rights.

28 That is the reason why historians have protested against the European Union Council Framework Decision 2008/913/JHA of 28 Nov 2008 on Combating Certain Forms and Expressions of Racism and Xenophobia by Means of Criminal Law (2008). See Luigi Cajani, "Historians under Criminal Law: EU Legislation Casts a Shadow on Historical Research", Perspectives on History, (www.historians.org/ perspectives), Oct 2009, and, Idem, Adoption de la décision-cadre européenne au 17 mai 2011 (Paris, 25 May 2011).

29 On 19 Jan 2007, journalist Hrant Dink was assassinated for his views on the Armenian genocide of 1915. On 14 Sept 2010, the ECHR unanimously ruled in Dink vs. Turkey that Turkey violated his right to life (by failing to prevent the murder although the police and gendarmerie had been informed of the likelihood of an assassination attempt and of the identity of the suspected instigators; and by not conducting an effective investigation into the failures which occurred in protecting Dink's life); and his right to free expression (a guilty verdict for "insulting and weakening Turkish identity through the media" had been handed down in the absence of a pressing social need, which made Dink a target for extreme nationalist groups). The ECHR concluded that Dink was indirectly punished for criticising the official denial of the view that the 1915 events amounted to genocide.

30 In another context, I tried to solve the problem whether the demarcation between the use and abuse of history is a traditional one that has always existed or a modern one. See Antoon De Baets, Responsible History, New York and Oxford: Berghahn, 2009, 39-48. 